\title{
Plerixafor verbessert die Mobilisierung in der autologen hämatopoetischen Stammzelltransplantation
}

Bei der Mobilisierung von hämatopoetischen Stammzellen für die autologe Stammzelltransplantation können Patienten mit Multiplem Myelom oder Lymphom von dem CXCR4-Antagonisten Plerixafor (Mozobil $\left.{ }^{\circledR}\right)$ profitieren: In Kombination mit dem Wachstumsfaktor G-CSF können mehr Patienten in weniger Apheresesitzungen die erforderliche Anzahl an CD34+ Stammzellen mobilisieren [1-2]. Dies macht die Apherese effizienter sowie besser planbar und ermöglicht letztendlich mehr autologe Transplantationen, so der Tenor der Experten bei einem Symposium, das im Rahmen des 31. Kongresses der International Society of Blood Transfusion (ISBT) sowie des 43. Kongresses der Deutschen Gesellschaft für Transfusionsmedizin und Immunhämatologie (DGTI) im Juni 2010 in Berlin stattfand [3].

Ziel der autologen Transplantation von Stammzellen ist es, die Dauer der Chemotherapie-induzierten Aplasie zu verkürzen sowie die behandlungsbedingte Morbidität und Mortalität zu reduzieren. Hauptindikationen sind Leukämien, lymphoproliferative Störungen, solide Tumoren und nichtmaligne Erkrankungen. So waren unter den insgesamt 16000 im Jahr 2008 in Europa durchgeführten autologen Stammzelltransplantationen ca. 13400 Patienten mit lymphoproliferativen Erkrankungen, 1400 Patienten waren an soliden Tumoren erkrankt und knapp 1000 litten an einer Leukämie [4]. «Die autologe Stammzelltransplantation bleibt dabei trotz der Einführung neuer Wirkstoffe wie Rituximab, Bortezomib, Thalidomid oder Lenalidomid eine wichtige Therapieoption v. a. bei Patienten mit hohem Rückfallrisiko oder, wenn mit herkömmlicher Therapie keine vollständige Remission erreicht werden kann», betonte Professor Dr. Christian Chabannon, Université de la Méditerranée, Aix-Marseille, Frankreich.

\section{G-CSF - ein wichtiger Meilenstein}

Bei der Entwicklung der Stammzelltransplantation stellte der Einsatz des rekombinanten Wachstumsfaktors G-CSF (granulocyte-colony stimulating factor) zur verstärkten Mobilisierung von Stammzellen aus dem Knochenmark in das periphere Blut einen wichtigen Meilenstein dar. Dies ermöglichte ab Mitte der 1980er Jahre den Ersatz von Knochenmarkstransplantaten durch Bluttransplantate. Da der Gehalt an Stammzellen im Transplantat den Erfolg der hämatopoe- tischen Stammzelltransplantation (HSZT) bestimmt, kann die Übertragung jedoch nur dann durchgeführt werden, wenn eine ausreichende Menge an CD34+ Zellen aus dem peripheren Blut gewonnen werden kann. Dabei gelten zwei Millionen CD34+Zellen pro kg Körpergewicht als Minimum für eine erfolgreiche Transplantation, wünschenswert ist jedoch eine Zielzellzahl von fünf Millionen Stammzellen pro kg Körpergewicht. Deshalb galt in der Folge die besondere Aufmerksamkeit möglichen Prädiktoren für eine erfolgreiche Mobilisierung und Strategien, mit denen einer schlechten Mobilisierung begegnet werden kann. Das bisher zur Mobilisierung von Stammzellen in das periphere Blut eingesetzte G-CSF hat den Nachteil, dass der ideale Zeitpunkt für die Apherese sowie die Anzahl der erforderlichen Sitzungen schlecht vorhersagbar sind. Bei einigen Patienten können trotz mehrerer Sitzungen im Verlauf von mehreren Tagen unter G-CSF allein nicht genügend CD34+ Zellen für eine Transplantation gesammelt werden. «Für diese Patienten stehen seit kurzem echte Verbesserungen zur Verfügung», so Chabannon: Eine neue Generation leistungsfähiger Zellseparatoren wurde eingeführt und der CXCR4Antagonist Plerixafor zugelassen.

\section{Plerixafor-Wirkmechanismus: First In-Class-CXCR4-Inhibitor}

Blutstammzellen (CD34+ Zellen) werden im Knochenmark über die Interaktion zwischen dem Chemokin-Rezeptor CXCR4 und dem Chemokin SDF-1 $\alpha$ gebunden. Um eine ausreichende Menge an Blutstammzellen für die Transplantation aus dem peripheren Blut gewinnen zu können, muss die Verbindung zwischen Stammzelle und Nische gelöst werden. Anders als G-CSF, das indirekt wirkt, beeinflusst das «small molecule» Plerixafor spezifisch und direkt die Verbindung zwischen CXCR4 und SDF-1 $\alpha$. Durch die Blockade der Bindung werden mehr Blutstammzellen vom Knochenmark gelöst und in das periphere Blutsystem entlassen. Im Zusammenspiel mit G-CSF nehmen die Geschwindigkeit und Effektivität der Mobilisierung signifikant zu. Dies bestätigen u. a. Daten von Liles et al. [5], die Dr. Catarina Geraldes, Universitätskrankenhaus Coimbra, Portugal, präsentierte: Der Einsatz von Plerixafor zusätzlich zu einem fünftägigen $\mathrm{G}$ CSF-Regime führte im Zeitfenster zwischen

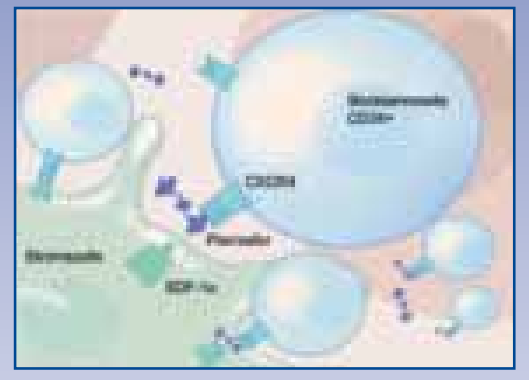

Abb. 1. Wirkmechanismus von Plerixafor

4 und 18 Stunden nach der Applikation zu einer signifikanten Erhöhung der peripheren CD34+Zellzahl $(n=10 ; p<0,05)$. Der Peak der CD34+ Zellen lag zwischen 10 und 14 Stunden nach der Plerixafor-Gabe.

\section{Zulassungsstudien: Signifikant bessere Mobilisierung bei Non-Hodgkin- Lymphom und Multiplem Myelom}

Die Fragestellung der von Geraldes präsentierten multizentrischen, randomisierten, doppelblinden, plazebokontrollierten Phase-IIIStudien [1-2] war es, Sicherheit und Wirksamkeit von Plerixafor plus G-CSF vs. GCSF-Monotherapie bei der Mobilisierung hämatopoetischer Stammzellen zur autologen Transplantation bei Patienten mit Non-Hodgkin-Lymphom (NHL, $\mathrm{n}=298$ ) bzw. Multiplem Myelom (MM, $n=302$ ) zu untersuchen.

\section{Mobilisierung bei Patienten mit}

Non-Hodgkin-Lymphom

In der NHL-Studie [1] wurden die Patienten nach der Randomisierung an acht aufeinanderfolgenden Tagen täglich mit $10 \mu \mathrm{g} \mathrm{G-}$ CSF pro kg Körpergewicht behandelt. Beginnend am Abend des vierten Tages erhielten die Patienten zusätzlich entweder 240 $\mu \mathrm{g}$ Plerixafor pro $\mathrm{kg}(\mathrm{n}=150)$ oder Plazebo ( $\mathrm{n}=148)$ für insgesamt vier Tage. Die Apheresesitzungen wurden am fünften Tag begonnen und bis einschließlich des achten Tages fortgeführt. Primärer Endpunkt der Untersuchung war der prozentuale Anteil der Patienten, bei denen $\geq 5 \times 10^{6}$ CD34+ Zellen pro $\mathrm{kg}$ in vier oder weniger Apheresesitzungen gesammelt werden konnten. Sekundäre Endpunkte waren der prozentuale Anteil der Patienten, die $\geq 2 \times 10^{6}$ 
CD34+ Zellen pro $\mathrm{kg}$ in vier oder weniger Apheresesitzungen erreichten, die Anzahl der Tage bis zum Anwachsen der Neutrophilen und Thrombozyten sowie die Transplantatbeständigkeit 100 Tage nach Transplantation.

90\% der Plerixafor-Patienten konnten transplantiert werden

$65,6 \%$ der Patienten unter Plerixafor erreichten in vier oder weniger Apheresetagen $\geq 5 \times 10^{6} \mathrm{CD} 34+$ Zellen pro $\mathrm{kg}$, gegenüber $24,2 \%$ in der Plazebo-Gruppe ( $<<0,0001)$ (Abb. 2). Darüber hinaus erreichten in der Plerixafor-Gruppe bereits nach einem Apheresetag mehr Patienten (27,9\%) diese Zellzahl als in der Plazebo-Gruppe nach vier Tagen $(24,2 \%)$. Während $90 \%$ der Plerixafor-Patienten transplantiert werden konnten, lag dieser Endpunkt mit 55\% der Patienten in der Plazebo-Gruppe deutlich niedriger $(p<0,001)$. Die Gabe von Plerixafor plus G-CSF war sicher und gut verträglich.

\section{Mobilisierung bei Patienten mit Multiplem Myelom}

In der Zulassungsstudie für Plerixafor beim MM [2] erhielten die Patienten nach der Randomisierung an vier aufeinander folgenden Tagen täglich $10 \mu \mathrm{g}$ G-CSF pro $\mathrm{kg}$, ab dem fünften Tag zusätzlich täglich $240 \mu$ g Plerixafor pro $\mathrm{kg}(\mathrm{n}=148)$ oder Plazebo $(n=150)$. Auch in dieser Studie wurden die Apheresesitzungen am fünften Tag begonnen und, soweit notwendig, bis einschließlich des achten Tages fortgeführt. Primärer Endpunkt war der prozentuale Anteil der Patienten, die $\geq 6 \times 10^{6}$ CD34+ Zellen pro kg in zwei oder weniger Apheresesitzungen erreichten. Sekundäre Endpunkte waren unter anderem der prozentuale Anteil der Patienten, die $\geq 2 \times 10^{6}$ oder $\geq 6 \times 10^{6} \mathrm{CD} 34+$ Zellen pro $\mathrm{kg}$ in vier oder weniger Apheresesitzungen erreichten, die Anzahl der Tage bis zum Anwachsen der Neutrophilen und Blutplättchen

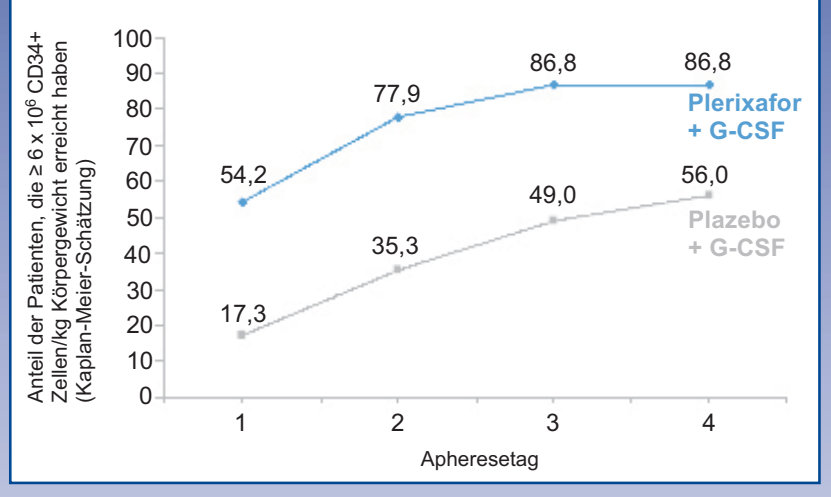

Abb. 3. Mobilisierung bei Patienten mit Multiplen Myelom. sowie die Transplantatbeständigkeit 100 Tage nach Transplantation.

\section{Rasches Erreichen der Zielzellzahlen}

Mehr als doppelt so viele Patienten $(77,9 \%)$ aus der Plerixafor-Gruppe erreichten die geforderten $\geq 6 \times 10^{6} \mathrm{CD} 34+$ Zellen pro kg in zwei oder weniger Apheresetagen, gegenüber 35,3\% in der G-CSF-Monogruppe ( $\mathrm{p}<0,0001)$ (Abb. 3). Die Gabe von Plerixafor plus G-CSF war auch in dieser Untersuchung sicher und gut verträglich. Fazit der Zulassungsstudien ist Geraldes zufolge, dass die Kombination aus Plerixafor und GCSF der alleinigen Gabe von G-CSF zur autologen Stammzelltransplantation bei Patienten mit NHL und MM signifikant überlegen ist. Mit Plerixafor wurde die notwendige und optimale Menge an CD34+ Zellen für die Transplantation in weniger Apheresetagen erreicht. In beiden Studien hatte die Mobilisierung mit Plerixafor plus G-CSF keinen Einfluss auf das Engraftment (Neutrophile und Thrombozyten) sowie auf die Beständigkeit der Transplantate.

\section{Poor Mobilizer - Patienten, die zu wenig Stammzellen mobilisieren}

Damit eine autologe Stammzelltransplantation erfolgreich durchgeführt werden kann, ist ein Minimum an Stammzellen im Transplantat

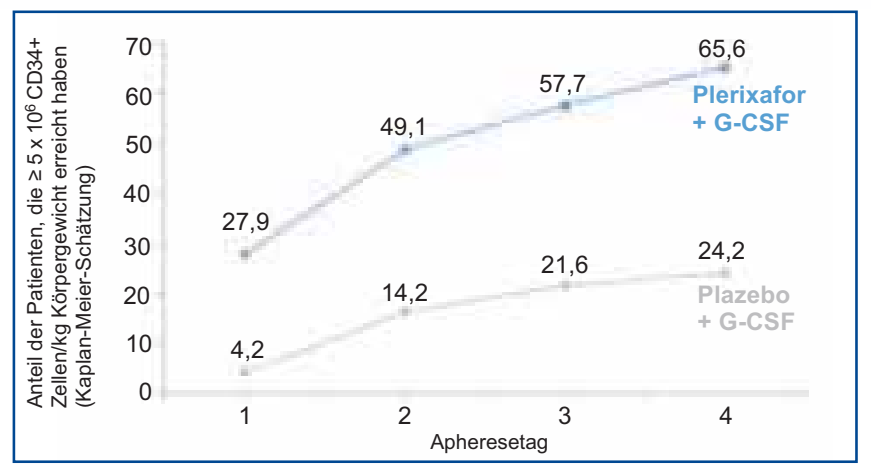

Abb. 2. Mobilisierung bei Patienten mit Non-HodgkinLymphom. erforderlich. PD Dr. Andreas Humpe, Universitäts-Krankenhaus Schleswig-Holstein, Kiel, präsentierte [3] dazu Daten von Giralt et al. [6], die für die Transplantation von Patienten mit $\mathrm{MM}$ eine minimale CD34+ Dosis von $4 \times$ $10^{6}$ Zellen pro kg und eine optimale Zellzahl von 8 bis $10 \times 10^{6}$ Zellen pro kg untersucht haben. Nach derzeitiger Auffassung liegt beim NHL die optimale CD34+ Zellzahl Humpe zufolge bei 4 bis $5 \times 10^{6}$ Zellen pro $\mathrm{kg}$.

\section{Versagerquoten variieren stark}

Diese Zahlen werden jedoch häufig nicht erreicht - betroffene Patienten werden als Poor Mobilizer bezeichnet. Professor Dr. Nina Worel, Universität Wien, Österreich, wies dabei auf die hohe Variabilität der nicht ausreichenden Mobilisierungen in der Literatur hin: Sie liegen je nach Studie beim MM zwischen 11 und 53\% und beim NHL bei etwa $5 \%$. In einer aktuellen Untersuchung gingen Pusic et al. [7] mit Hilfe einer retrospektiven Analyse der Frage nach, wie häufig die Mobilisierung nach einer Chemomobilisierung (Chemotherapie gefolgt von G-CSF) oder nach einem Steady-State-Regime mit G-CSF allein versagt: Von den 1040 Patienten, die eine autologe HSZT erhalten hatten, waren 5,9 bzw. 6,3\% der MM-Patienten und 22,9 bzw. 26,8\% der NHL-Patienten betroffen. Die Kombination mit einer Chemotherapie beeinflusste die Versagerquoten nicht.

Uneinheitliche Definitionen von fehlgeschlagener Mobilisierung

Hintergrund der stark variierenden Raten an Poor Mobilizern sind Worel zufolge neben einer Vielzahl verschiedener Mobilisierungsregime auch von Zentrum $\mathrm{zu}$ Zentrum unterschiedliche Definitionen eines fehlgeschlagenen Mobilisierungsversuchs. So werden als Kriterien für ein 
Therapieversagen u. a. folgende Parameter gewählt:

\section{Zahl der zirkulierenden CD34+ Zellen}

Nichterreichen der minimalen Zahl an CD34+ Zellen

Nichterreichen der optimalen CD34+ Zellzahl

keine Hochdosis-Chemotherapie möglich. Um für mehr Klarheit zu sorgen, hat die Arbeitsgruppe von Wuchter et al. [8] anhand einer retrospektiven Analyse bei 840 Patienten (602 MM, 238 NHL), verschiedene Gruppen von Poor Mobilizern (< 20 CD34+

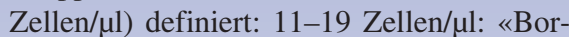
derline Poor Mobilizer», 6-10 Zellen/ $\mu$ : «Relative Poor Mobilizer» und $\leq 5$ Zellen/ $\mu$ : «Absolute Poor Mobilizer». Eine praxisnahe Definition der Poor Mobilizer hat auch die italienische Arbeitsgruppe Trapianto Midollo Osseo (GITMO) vorgeschlagen (siehe Kasten) [4].

\section{Suboptimale Mobilisierung - Risikofaktoren} und Konsequenzen

Besonders häufig ist Worel zufolge eine schlechte Mobilisierung von Stammzellen bei Patienten, die älter als 60 Jahre sind, oder unter bestimmten Grunderkrankungen leiden sowie bei vorangegangener Radio- und Chemotherapie, einer Behandlung mit Melphalan, Carmustin oder Fludarabin in der Anamnese oder unter neuen Induktionsstrategien (z.B. Lenalidomid beim MM). Kann keine ausreichende Zahl an CD34+ Zellen im Knochenmark mobilisiert werden, so erhöht sich die Zahl der Apheresetage; die Gewinnung von Knochenmark ist möglicherweise erforderlich oder die Transplantation kann unter Umständen überhaupt nicht durchgeführt werden.
Wiederholte Mobilisierungsversuche belasten darüber hinaus den Patienten, sind mit höherer Morbidität sowie Versagerquoten assoziiert und steigern den Ressourcenverbrauch. Der Gebrauch von Aphereseprodukten mit suboptimalem Ertrag kann dazu führen, dass die Stammzellen verspätet, nur teilweise oder gar nicht anwachsen. Das Risiko für Infektionen und/oder Blutungen ist ebenso erhöht wie das Risiko für Transfusionen.

Patienten profitieren vom Plerixafor-RescueProtokoll der Zulassungsstudien

Die von Worel präsentierten Rescue-Protokolle der beiden Zulassungsstudien von DiPersio [1-2] machen deutlich, dass Patienten, die unter GCFS allein nur unzureichend Stammzellen mobilisieren, von einer Plerixafor-Gabe profitieren: 10 Patienten der G-CSF/Plerixafor-Gruppe und 52 Patienten der Plazebo-Gruppe von den insgesamt 298 NHL-Patienten konnten in der Phase-III-Studie nicht ausreichend mobilisert und deshalb nicht transplantiert werden [9]. Im Rahmen des Rescue-Protokolls wurden sie mit G-CSF/Plerixafor behandelt. Anschließend war bei $60 \%$ der Patienten der ursprünglichen Verum-Gruppe und $88 \%$ der ursprünglichen Plazebo-Gruppe doch noch eine ausreichende Zellzahl zu erzielen und die Transplantation war möglich. Alle Plerixafor-Patienten mit MM (302) konnten transplantiert werden, bei sieben Patienten der Plazebo-Gruppe war die Mobilisierung nicht ausreichend. Nach Behandlung mit Plerixafor im Rahmen des Rescue-Protokolls konnten alle verbliebenen MMPatienten transplantiert werden. Worel zufolge ermöglicht die Verfügbarkeit von Plerixafor heute eine frühe Intervention bei nachgewiesenen und wahrscheinlichen Poor Mobilizern.

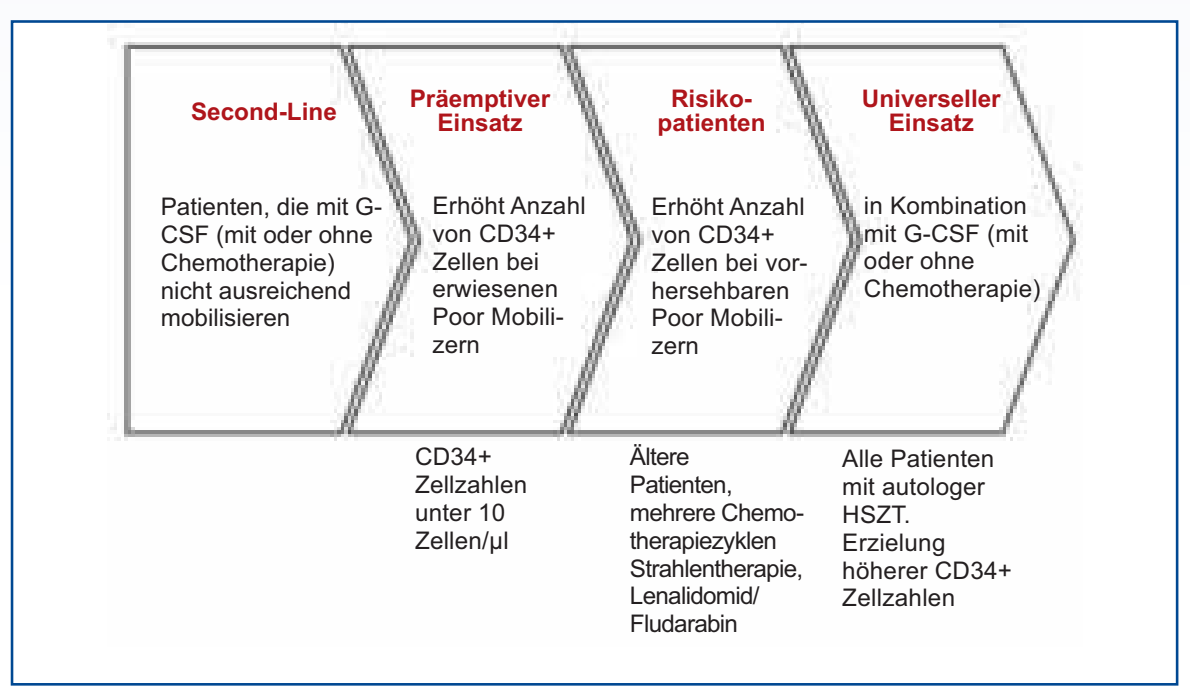

Abb. 4. Notwendigkeit zum Einsatz neuer Strategien für die autologe Stammzellmobilisierung.

\section{Poor Mobilizer - die GITMO-Definition}

Die Studiengruppe GITMO (Gruppo Italiano Trapianto Midollo Osseo) hat folgende Definitionen für Poor Mobilizer entwickelt [4]:

\section{Belegte Poor Mobilizer:}

Patient mit MM oder NHL, der eine HSZT benötigt und der

- nach einer adäquaten Mobilisierung mit G-CSF Peak-Zellzahlen (CD34+) von < 20 Zellen/ $\mu$ l am Tag 4 bis 6 nach dem Start der Mobilisierung mit G-CSF alleine oder nach Tag 18 bis 20 nach Chemotherapie und G-CSF zeigt oder

$-<2,5 \times 10^{6}$ gesammelte CD34+ Zellen $/ \mathrm{kg}$ Körpergewicht pro geplanter Stammzelltransplantation bei drei oder weniger Apheresesitzungen erreicht.

\section{Wahrscheinliche Poor Mobilizer:}

Patient mit MM oder NHL, der eine HSZT benötigt und der mindestens ein Hauptkriterium oder zwei Nebenkriterien erfüllt.

\section{Hauptkriterien:}

- vorangegangener Mobilisierungsversuch fehlgeschlagen

- extensive Radiotherapie auf Knochenmarksgewebe in der Anamnese

- Vortherapie kompletter Zyklen mit Melphalan, Fludarabin oder anderen Therapien, die die Stammzellmobilisierung beeinflussen können

Nebenkriterien:

- fortgeschrittene Erkrankung, z. B. nach zwei oder mehr zytotoxischen Therapielinien

- refraktäre Erkrankung

- extensive Knochenmarksbeteiligung bei der Mobilisierung

- Knochenmarkszellularität zum Zeitpunkt der Mobilisierung unter 30\%

- Alter über 65 Jahre

Sie plädierte deshalb für einen präemptiven Therapieansatz bei der Behandlung mit Plerixafor, um optimale Transplantationsraten zu erzielen. Für die Zukunft sieht Worel neben dem SecondLine-Einsatz von Plerixafor bei Patienten, die bereits einen fehlgeschlagenen Mobilisierungsversuch hinter sich haben, hier die wesentliche Einsatzmöglichkeit für den CXCR4-Antagonisten (Abb. 4).

\section{Maßgeschneiderte Strategien für die Sammlung von hämatopoetischen Stammzellen}

Ziel der Mobilisierung ist es, grundsätzlich einen ausreichenden bzw. optimalen Ertrag an peripheren Stammzellen mit einem Minimum an Apheresesitzungen zu erreichen. Humpe erklärte [3], dass dabei sowohl die Mobilisierungs- als auch die Sammelstrategien auf die individuellen Bedürfnisse des Patienten zugeschnitten sein sollten, und machte dies anhand eines individuellen Dosierungsschemas für Plerixafor deutlich 


\section{Innovationen • Innovations}

(Abb. 5). Humpe unterstrich dabei, dass die CD34+ Zellausbeute bei der Apherese nicht nur von der Anzahl an CD34+ Zellen im peripheren Blut, sondern auch maßgeblich von der Dauer, vom Volumen und von der Fließgeschwindigkeit der Apherese ( $\mathrm{ml} / \mathrm{min})$ abhängt. Für einen optimalen Ertrag müssen diese Parameter jeweils angepasst werden. Als Benchmark gelten Humpe zufolge eine Apheresedauer zwischen 120 und $300 \mathrm{~min}$, die Fließgeschwindigkeit sollte zwischen 50 und $65 \mathrm{ml} / \mathrm{min}$ liegen. Abschließend fasste Humpe [3] zusammen: «Unter dem Einsatz von Plerixafor ist die Stammzellmobilisierung und -sammlung bei Patienten mit suboptimaler Mobilisierung besser planbar und kalkulierbar und ermöglicht oft erst die autologe Stammzelltransplantation.»

\section{Erfahrungen aus dem deutschen Compassionate-Use-Programm}

Insgesamt 60 Patienten, bei denen die Mobilisierung fehlgeschlagen war, wurden im Rahmen des deutschen CompassionateUse-Programms an 23 Zentren mit Plerixafor behandelt. Sie litten überwiegend an MM sowie NHL und erhielten $240 \mu \mathrm{g}$ Plerixafor pro kg s.c. 9-11 Stunden vor der geplanten Apheresesitzung. 78,3\% (47/60) erhielten an mindestens vier Tagen vor der Plerixafor-Gabe zusätzlich G-CSF. Bei $76,6 \%$ dieser Patienten (36/47) konnten $\geq$ $2,0 \times 10^{6} \mathrm{CD} 34+$ Zellen pro kg gesammelt werden, der mediane Zellertrag lag bei $3,35 \times 10^{6}$ CD34+ Zellen pro kg. Neun Pa-

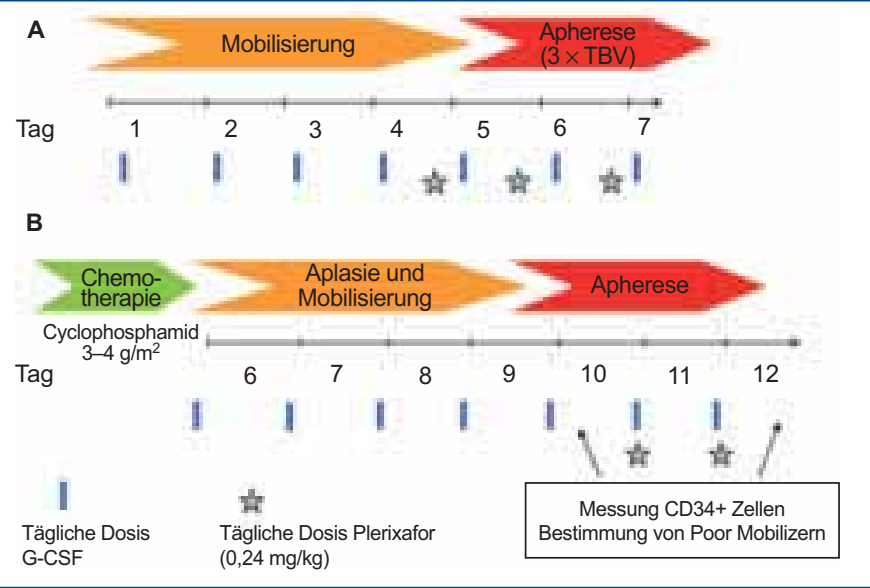

Abb. 5. Mobilisierungsschema nach DiPersio et al. (A) und beispielhaftes Mobilisierungsschema von Humpe (B) tienten erhielten entweder Plerixafor allein oder in Kombination mit G-CSF über weniger als vier Tage. Sie erzielten in der Apherese durchschnittlich $3,3 \times 10^{6}$ CD34+ Zellen pro kg. Es gab also keinen signifikanten Unterschied beim Zellertrag zwischen der viertägigen und der kürzeren Anwendungsdauer $(\mathrm{p}=0,157)$. 47 Patienten erhielten Plerixafor plus G-CSF in Kombination mit einer Chemotherapie und erreichten durchschnittlich $3,28 \times 10^{6}$ CD34+Zellen pro kg. 40 Patienten (66,7\%) konnten transplantiert werden und erreichten ein zeitgerechtes und stabiles Engraftment. Plerixafor war gut verträglich. Fazit der Autoren: Die Mobilisierung mit Plerixafor ist bei Poor Mobilizern sicher und führt bei $75 \%$ der Patienten zu einer ausreichenden CD34+ Ausbeute. Plerixafor

\begin{tabular}{|c|c|c|c|}
\hline & G-CSF-Monotherapie & G-CSF + Chemotherapie & G-CSF + Plerixafor \\
\hline Vorteile & $\begin{array}{l}\text { - geringerer Ressour- } \\
\text { cenverbrauch } \\
\text { - geringe Toxizität } \\
\text { - ambulante Patienten }\end{array}$ & $\begin{array}{l}\text { • höhere hämatopo- } \\
\text { etische Stammzellerträge } \\
\text { • weniger Apherese- } \\
\text { sitzungen } \\
\text { • Anti-Tumor-Aktivität } \\
\text { • vergleichbare Engraft- } \\
\text { ment-Charakteristiken }\end{array}$ & $\begin{array}{l}\text { - höhere hämatopoetische } \\
\text { Stammzellerträge } \\
\text { - gute Verträglichkeit } \\
\text { - weniger Apheresesitzungen } \\
\text { - gute Planbarkeit der } \\
\text { Apherese } \\
\text { - promptes und dauerhaftes } \\
\text { Anwachsen des } \\
\text { Transplantats } \\
\text { - einfache Handhabung } \\
\text { - Vorteile in Bezug auf } \\
\text { Logistik und Ressourcen }\end{array}$ \\
\hline Nachteile & $\begin{array}{l}\text { - kein Anti-Tumor- } \\
\text { Effekt } \\
\text { - höhere Versagerraten } \\
\text { bei der Mobilisierung } \\
\text { - signifikant erhöhte } \\
\text { Morbidität (z. B. } \\
\text { Knochenschmerzen, } \\
\text { Kopfschmerzen) }\end{array}$ & $\begin{array}{l}\text { - höhere Toxizität und } \\
\text { Hospitalisierungsraten } \\
\text { - Schädigung des } \\
\text { Knochenmarks möglich } \\
\text { • höherer Ressourcen- } \\
\text { verbrauch } \\
\text { - schlechtere } \\
\text { Vorhersagbarkeit }\end{array}$ & - kein Anti-Tumor-Effekt \\
\hline
\end{tabular}

Tab. 1. Verschiedene Mobilisierungsregime im Vergleich (nach Worel und Geraldes) war dabei auch bei Patienten wirksam, die an anderen (malignen) Erkrankungen litten, die eine Hochdosis-Chemotherapie und eine autologe Transplantation erfordern [10].

Monika Walter, München

\section{Referenzen}

1 DiPersio et al.: J Clin Oncol 2009;27:4767-73

2 DiPersio et al.: Blood 2009;113:5720-26.

3 Symposium von Genzyme: «Emerging role of Plerixafor in stem cell mobilization and apheresis», im Rahmen des 31. Internationalen Kongresses der ISBT in Kooperation mit dem 43. Kongress der DGTI, 28. Juni 2010, Berlin.

4 Symposium von Genzyme: Vortrag von Lemoli $\mathrm{R}$ «Risk factors for poor mobilisation and clinical options for intervention», 36th Annual Meeting of the European Group for Blood and Bone Marrow Transplantation (EBMT), Wien, Österreich, 21. März 2010.

5 Liles et al.: Transfusion 2005;45:295-300.

6 Giralt et al.: Leukemia 2009;23:1904-12.

7 Pusic et al.: Biol Blood Marrow Transplant 2008;14:1045-56.

8 Wuchter et al.: Biol Blood Marrow Transplan 2010;16:1-10.

9 Micallef et al.: Biol Blood Marrow Transplant 2009;15:1578-86.

10 Hübel et al.: Bone Marrow Transplant 2010;45(S316): P1005.

\section{Impressum}

\section{CXCR4-Antagonist:}

Plerixafor verbessert die Mobilisierung in der autologen hämatopoetischen Stammzelltransplantation

Innovationen in

Transfusion Medicine and Hemotherapy 37 | 5 | 10

(C) 2010 by S. Karger Verlag für Medizin

und Naturwissenschaften $\mathrm{GmbH}$

Wilhelmstraße 20A

79098 Freiburg, Deutschland

Mit freundlicher Unterstützung der Genzyme GmbH.

Der Verlag und die Herausgeber der Zeitschrift übernehmen keine Verantwortung für diese Rubrik. 


\section{Hemophilic Arthropathy: New Insights into Mechanisms, Prevention and Management}

Hemophilic arthropathy is a significant complication in patients with hemophilia, resulting in considerable morbidity and a reduction in quality of life. The pathogenesis of hemophilic arthropathy remains incompletely understood, although evidence from animal and human studies has provided insights into specific mechanisms. Routine prophylaxis is an important treatment strategy for patients with severe hemophilia, and trials such as the Joint Outcome Study have made important contributions to the optimization of prophylactic therapy in clinical care. When medical management fails to prevent the development of arthropathy, techniques such as radiosynovectomy, chemical synoviorthesis, and arthroscopic synovectomy can be used to manage chronic synovitis. Expert opinion considers radiosynovectomy to be the most cost-effective, efficacious and convenient therapy for the patient and suggests that it should be considered as the first-line non-medical treatment. While progress has been made in the treatment of arthropathy, the primary goal should be to prevent hemorrhage that leads to joint damage. To attain this goal, the development of novel coagulation factors that show equal or enhanced efficacy and tolerability, yet are able to extend duration of action due to a prolonged plasma half-life or other cellular effects, is currently under way. It is hoped that such products will provide a better quality of life for patients by reducing the burden of their treatment protocol.

In 2009, the biennial congress hosted by the International Society on Thrombosis and Haemostasis (ISTH), was held in Boston, Massachusetts, between the $11^{\text {th }}$ and $16^{\text {th }}$ of July. The major focus of the congress was the important medical problem of thrombosis and abnormalities of hemostasis and vascular biology; a comprehensive scientific program of satellite symposia, oral communications, and poster presentations provided attendees with further insight into topics such as platelet immunology, hemostasis and malignancy, and women's health issues in thrombosis and hemostasis. This report is a summary of one of the symposia held at the congress, entitled Hemophilic Arthropathy: New Insights into Mechanisms, Prevention and Management, which was attended by over 700 delegates. The objectives of the session were to understand the biology of blood-induced joint disease, appreciate the benefits of regular factor replacement to prevent joint disease, understand the interventions available to counter the effects of hemophilia, and gain knowledge of the new pipeline of products in development by Bayer HealthCare Pharmaceuticals to treat hemophilia.

\section{Biology of Joint Disease}

Hemophilic arthropathy is caused by bleeding into the joint capsule, which leads to hypertrophy and inflammation of the synovium and eventually the development of arthritis. Over a quarter of patients with severe hemophilia A develop at least one target joint, which manifests clinically as a loss of range of joint motion and increased joint complications [1, 2]. Quality of life (QoL) and day-to-day functioning are further impaired in patients with hemophilia, with the degree of impairment being strongly correlated with disease severity $[3,4]$. Therefore, to reduce patient disability and improve QoL, the prevention and treatment of hemophilic arthropathy are very important considerations.

Etiology and Pathogenesis of Joint Disease Leonard Valentino from RUSH University Medical Center, Chicago, discussed the factors that increase the risk of a patient developing joint disease, and summarized the processes by which joint disease develops. Bleeding into a joint is the most significant risk factor for arthropathy and usually begins at an early age in patients with severe hemophilia. In a prospective study of 37 previously untreated patients (PUPs), 44\% suffered their first hemorrhage within the first year of life; the mean age for the first hemarthrosis was 1.9 years [5]. A retrospective cohort study examining the effect of postponing prophylactic therapy on long-term arthropathy in 76 PUPs with severe hemophilia additionally found that, by the age of 4.4 years, $90 \%$ of patients had experienced at least one hemarthrosis [6].

The number of hemarthroses experienced by a patient also has an impact on the development and severity of joint disease. In a cohort of 76 patients with severe hemophilia, the early initiation of prophylaxis resulted in complete prevention of joint damage for $70 \%$ of patients, compared with $31 \%$ of patients who started after three or more hemarthroses. In addition, the severity of arthropathy, as measured by the Pettersson score, increased progressively with increasing number of hemarthroses before prophylaxis [6].
The pathogenesis of hemophilic arthropathy is a multifactorial process. An acute joint hemorrhage is accompanied by pain and swelling; motion is also limited due to inflammation and an increase in intra-articular pressure. Cartilage cell apoptosis occurs, which is a result of mechanical signals induced by the increase in pressure. Blood in the joint space provokes synovial cell proliferation and leads to the development of hemophilic synovitis [7]. Eventually, chronic hemophilic arthropathy develops, which is characterized by muscle atrophy, ankylosis, cartilage degeneration, collapse of the joint space, osteoporosis and bone cysts (fig. 1).

\section{Evidence from Murine Models}

Although it is widely known that bleeding into a joint leads to progressive deterioration of joint function culminating in arthropathy, there is still limited understanding of the mechanism and mediators involved in the pathway. The process is very difficult to study in humans due to the inability to access joint tissue after just one or two bleeding episodes. However, this problem has been partially resolved by using hemophilic mice to model the development of arthropathy.

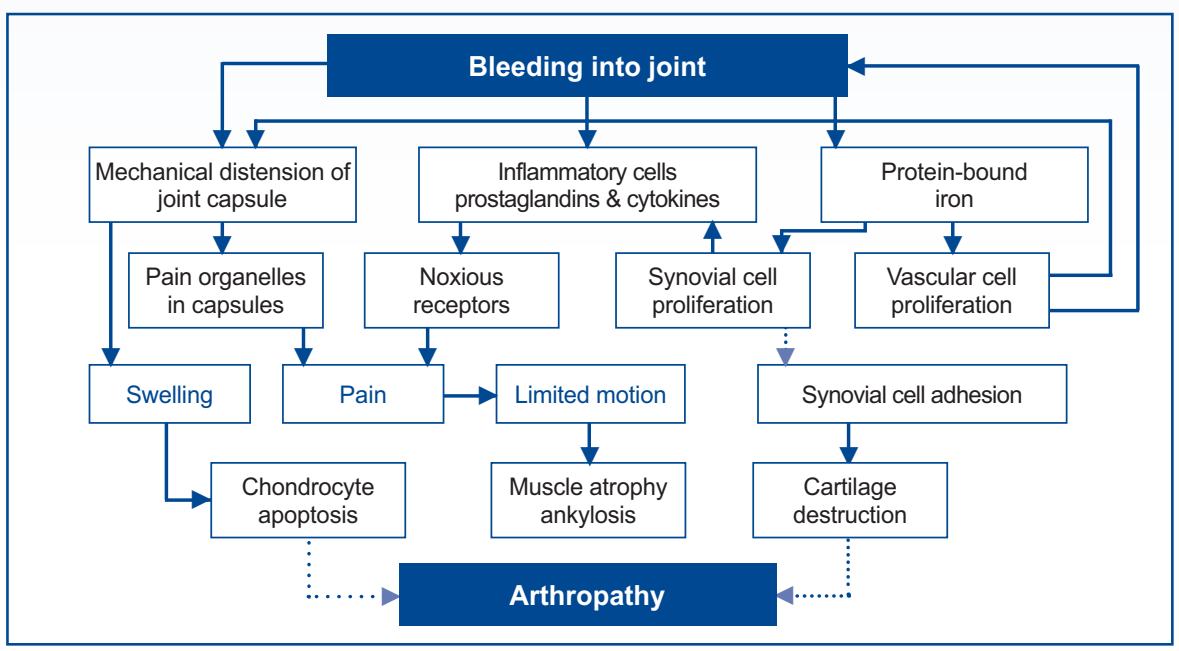

Fig. 1. Pathophysiological processes involved in the development of hemophilic arthropathy. 
Immunohistochemical staining for the cell proliferation marker Ki67 has revealed that the cells in the border of the synovial villi proliferate at a highly accelerated rate. Accelerated proliferation also occurs in the sub-synovial layer. Further staining using Prussian blue demonstrates that iron deposition occurs within areas containing a high concentration of Ki67, suggesting that iron may be one of the causative agents of increased cell proliferation. To model massive hemarthrosis, the hind-limb knee joints of both hemophilia A mice and normal wild-type mice were punctured using a $30-$ gauge needle, and a small amount of pressure was applied. In the hemophilia A, but not the wild-type mice, this procedure resulted in profuse bleeding into the joint as well as in swelling of both the soft tissues and membranes within the joint space. Hemarthrosis in the hemophilia A mice further led to the development of necrosis of the soft tissue 3 days following the injury. These effects were prevented by the administration of factor VIII (FVIII) concentrate prior to the injury.

Fourteen days following the needle-puncture injury and massive hemarthrosis, changes to the joint were visible radiographically; a decreased range of motion in the injured joint compared with the contralateral control joint was also determined by physical examination. Other changes seen 30 days following joint puncture included widening of the intra-condylar notch, hyperplasia of the femoral condyles, a radio-dense effusion within the joint space, and narrowing of the joint space. MicroCT scanning further revealed multiple osseous abnormalities in the surface contour of the joint and marked loss of osseous volume in the joint at 14 and 30 days post-injury, respectively, compared with the uninjured joint.

An additional phenomenon that has been shown experimentally is the loss of proteoglycans from the cartilage. Using Alcian blue staining, cartilage destruction was shown to be most prominent at the articular surfaces and epiphyseal plates of the femur and tibia.

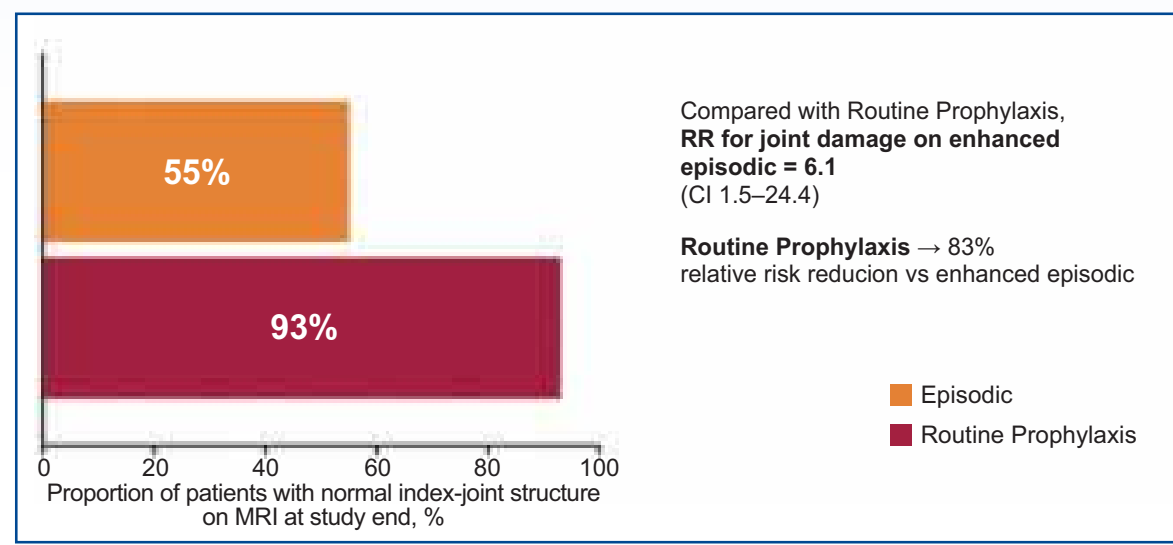

Fig. 2. Primary outcome of Joint Outcome Study showing the percentage of boys with normal index-joint structure on MRI at study end.
There are several treatments available for the prevention of hemophilic arthropathy that act by disrupting pathways in the pathogenesis of the disease. Prophylaxis of hemarthrosis by routine administration of FVIII concentrate is a highly effective therapy; however, it is not perfect, and some patients may still go on to develop joint disease. Joint aspiration has been used to release pressure in the joint, and may be combined with other treatment options such as washing of the joint cavity with saline or instilling corticosteroids or possibly biological response modifiers. Cytokine blockade and anti-proliferative therapy are two other treatment modalities that are currently being investigated in addition to novel treatments such as regrowth of bone and cartilage.

Routine Prophylaxis in Hemophilia A: Lessons from the US Joint Outcome Study (JOS)

Clotting factor concentrates were first used as prophylactic therapy in 1958 by Professor Nilsson in Sweden, whose research demonstrated that severe hemophilia can be reduced to a moderate type and that bleeding episodes and arthropathy can be prevented by prophylaxis [8]. Since then, evidence of the long-term benefit of prophylactic treatment has increased, and it has become the recommended treatment strategy for children with severe hemophilia by both the World Health Organization and the US National Hemophilia Foundation Medical and Scientific Advisory Committee [6]. Nevertheless, questions still remain as to when prophylaxis should begin, what dose of FVIII should be administered, and for how long prophylaxis should be provided [9].

Routine Prophylaxis versus Enhanced Episodic Treatment in Children

Marilyn Manco-Johnson of the University of Colorado discussed the key results from the US JOS and presented data on additional observations from

Compared with Routine Prophylaxis,

\section{Routine Prophylaxis $\rightarrow 83 \%$}

relative risk reducion vs enhanced episodic

Episodic

Routine Prophylaxis routine prophylaxis group, there were no significant differences in physical exam scores between the two groups until the children reached 5 years of age. This suggests that most findings on physical y experienced a significantly greater number therapy experienced a significantly greater number
of bleeding events each year compared with the

the trial that had not previously been published. This included 10 key lessons learned from the trial, five of which are discussed in this report.

The JOS was a randomized, multi-center, openlabel trial. A total of 65 boys aged less than 30 months were randomized to receive routine prophylaxis $(\mathrm{n}=32)$ or enhanced episodic therapy $(\mathrm{n}=33$ ) for a mean duration of 49 months [9]. The primary outcome was preservation of index-joint structure (including ankles, knees and elbows), as determined by means of MRI and plain-film radiography at the completion of the study (when the boys reached 6 years of age). A total of $93 \%$ of boys in the routine prophylaxis group, and 55\% of boys in the enhanced episodic-therapy group were considered to have normal index-joint structure on MRI $(\mathrm{P}=0.006)$ at study completion [9]. The mean annual numbers of joint and total hemorrhages were higher at study exit in the enhanced episodictherapy group than in the routine prophylaxis group ( $\mathrm{P}<0.001$ for both comparisons) [9]. Overall, patients receiving routine prophylaxis had an $83 \%$ reduction in the risk of joint damage as determined by MRI compared with patients receiving enhanced episodic therapy. Based on these results, the first lesson learned from the JOS is that routine prophylaxis is more efficacious than enhanced episodic therapy for the prevention of joint disease in young children with hemophilia A with no pre-existing joint damage (fig. 2).

A second lesson learned from the trial is that joint hemorrhage can be subclinical. This conclusion was based on the relationship between MRI scores and total number of hemarthroses. For example, some subjects had abnormal MRI scores despite no clinically evident hemarthrosis, whereas other subjects had normal MRI scores despite multiple hemarthroses. Bone and cartilage damage detected on MRI was not correlated with hemarthroses $(\mathrm{P}=0.63)$, and overall the correlation of hemarthroses with MRI scores was weak [9]. Additionally, a small proportion of patients in both treatment groups exhibited hemosiderin deposition into the synovium, indicating that blood breakdown within the joint occurred even in the absence of obvious hemarthrosis.

Joint abnormalities were not apparent on physical examination in the very young children in the study, suggesting that physical examination is not a sensitive predictor of joint damage. An examination of the correlation between annual bleeding events experienced by children in both treatment groups and annual joint physical examination scores indicated that while children receiving enhanced episodic 
examination were related to the development of synovitis and that many children did not experience a synovial reaction until bone and cartilage damage had already occurred.

A third lesson learned from JOS is that hemophilia A with a baseline level of FVIII between 1 and $2 \%$ is not necessarily less severe than a baseline FVIII level of $<1 \%$. The children in the study were separated into two groups, $<1 \mathrm{U} / \mathrm{dL}$ and $\geq 1 \mathrm{U} / \mathrm{dL}$, depending on their baseline level of FVIII. No significant differences were found between the two groups in terms of MRI outcome, number of joint hemorrhages and FVIII trough levels on routine prophylaxis.

One of the biggest challenges of starting early primary prophylaxis is venous access, with concerns primarily focused on infection rates in children with ports that are frequently accessed. Using data from the JOS, the association between central venous access device (CVAD)-related infection and treatment regimen was evaluated in a separate study [10]. The crude, and age- and household-adjusted rate ratios for first CVADrelated infection per 1,000 CVAD days were not significantly different between the prophylaxis and episodic-therapy groups [10]. A fourth lesson learned was therefore that every-other-day port access does not increase the infection rate.

Although the efficacy of prophylaxis with recombinant FVIII is supported by the JOS (the first randomized controlled trial to compare routine prophylaxis and enhanced episodic therapy), questions still remain that require further investigation. These include the functional significance of minimal early bone and cartilage abnormalities, the minimal FVIII trough level required to prevent joint damage, the natural history of the disease on routine prophylaxis, and the role of the inflammatory response.

\section{When Medical Management Fails to Pre- vent Arthropathy}

Carlos Rodriguez-Merchan discussed the options for the non-medical management of chronic synovitis and reviewed the advantages and disadvantages of radiosynovectomy, chemical synoviorthesis and arthroscopic synovectomy. $\mathrm{He}$ further explored the role of the orthopedic surgeon in improving surgical outcomes in patients with severe arthropathy and discussed his experiences of treating arthropathy at the Department of Orthopedics and Hemophilia Unit at La Paz University Hospital, Spain.

The most appropriate molecules for use in radiosynovectomy are Yttrium-90 at a dose of $185 \mathrm{MBq}$ for the knees and Rhenium-186 at a dose of 56$74 \mathrm{MBq}$ and $74 \mathrm{MBq}$ for the elbows and ankles, respectively, based on measures of the radioactive half-life and therapeutic penetration power [11].
The usual treatment regimen is a maximum of 3 injections given at 3- to 6-month intervals. The technique is highly cost effective in comparison to arthroscopic synovectomy and, in 429 procedures performed by Dr Rodriguez-Merchan at La Paz University Hospital in Madrid, was able to reduce bleeding frequency by a median of $85 \%$. In other studies, radiosynovectomy was found to reduce hemarthrosis by $59-100 \%$ in $53-100 \%$ of patients [12-15].

Chemical synoviorthesis is most commonly performed using rifampicin or oxytetracycline chlorhydrate. The technique is not widely used due to the pain and inconvenience to the patient; however, it may have some utility in developing countries where the radioactive substances required for radiosynovectomy are not available [16].

There are mixed views as to whether arthroscopic synovectomy should be considered as first- or second-line therapy in patients with chronic synovitis. In a study of 20 children with moderate or severe hemophilia, synovectomy significantly reduced the frequency of hemarthrosis in the first year. In addition, $76 \%$ of patients had stable or improved joint function at their most recent comprehensive clinic visit [17]. In a further study of 44 pediatric patients undergoing synovectomy as firstline therapy, a median hemarthrosis frequency decline of $84 \%$ was reported $(\mathrm{P}<0.001)$. The median arc of motion was stable or improved in the year after surgery in ankles, elbows and shoulders; however, radiographic scores worsened slightly [18]. At the Department of Orthopedics and Hemophilia Unit at La Paz University Hospital in Spain, arthroscopic synovectomy is used only as a secondline therapy after the failure of three radiosynoviortheses with 3- to 6-month intervals [11]. This technique has so far only been required in $3.5 \%$ of patients.

Total knee replacement (TKR) is indicated if a patient suffers severe pain and disability after the failure of conservative treatment such as prophylaxis, physiotherapy or radiosynoviorthesis. The presence of HIV, HCV or inhibitors is not a contraindication. In a series of 35 patients undergoing TKR, $90 \%$ of the procedures were considered to be excellent or good according to the Knee Society scoring system. A total of $10 \%$ of patients suffered complications. These included three deep infections (two early and one late), which required two-stage revision arthroplasty in 2 patients, and one case of pseudoaneurysm that required embolization. Survival of the prostheses at 7.5 years post-surgery was approximately $97 \%$ [19].

\section{Clinical Investigations of Long-Acting rFVIII Formulation and Novel rFVIla Product}

The circulatory half-life of human FVIII is approximately $10-12 \mathrm{~h}$; therefore, infusions typically need to be repeated every 2-3 days in order to maintain a FVIII level above $1 \%$ [20]. Such a dosing protocol places a great burden on patients to be compliant with their therapy; treatment compliance has been inversely linked to the number of infusions given, with compliance increasing as the number of infusions decreased [20]. A FVIII molecule or product formulation with extended half-life could therefore greatly improve the efficacy and QoL associated with prophylaxis in patients with hemophilia A [20]. Georg Lemm of Bayer HealthCare Pharmaceuticals discussed the clinical development of BAY 794980* a recombinant FVIII product that has been formulated with sucrose (rFVIII-FS) and bound non-covalently with PEGylated liposomes to prolong hemostatic efficacy. In a murine tail vein transection (TVT) model, BAY 79-4980 significantly improved survival $24 \mathrm{~h}$ post-dosing compared with rFVIII-FS reconstituted with sterile water for injection $(\mathrm{P}<0.05)$. Preliminary clinical data in 89 patients collectively receiving 150 infusions of BAY 79-4980 have demonstrated good tolerability and an extension of the time to next bleed compared with rFVIII-FS reconstituted with water for injection. A phase II multinational, randomized, active-controlled trial (LIPLONG) is underway comparing the efficacy of once-weekly

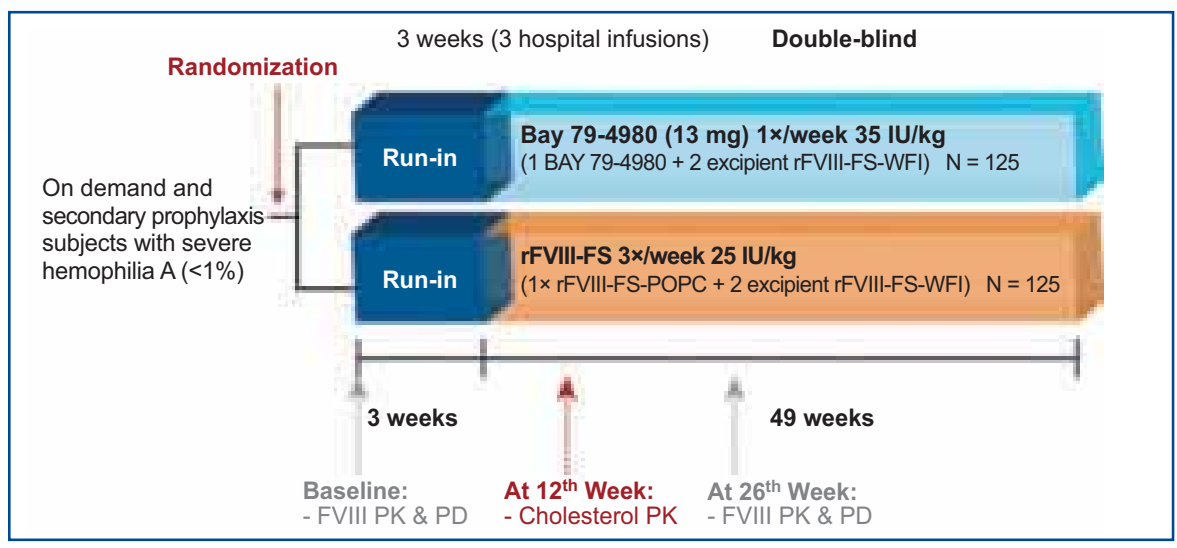

Fig. 3. LIPLONG study design. 


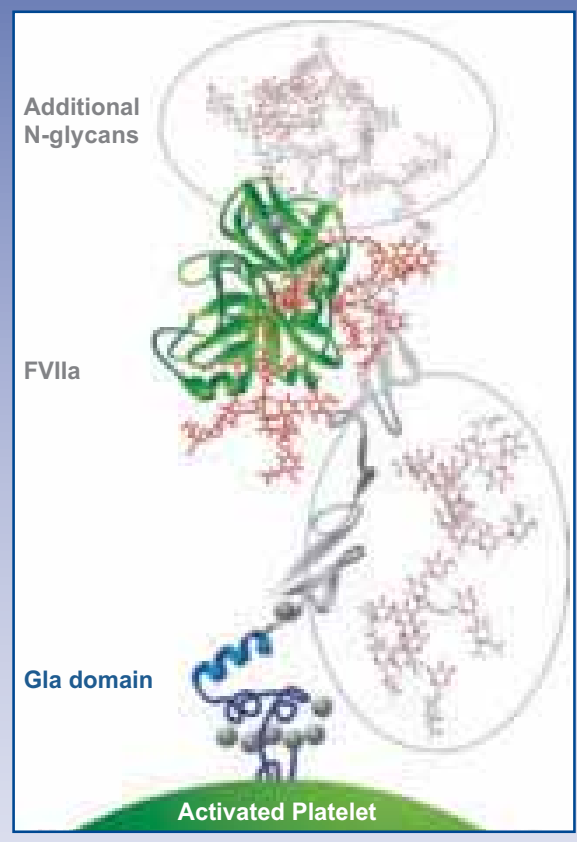

Fig. 4. The BAY 86-6150 molecule showing engineered segments.

BAY 79-4980 $(\mathrm{n}=125)$ with three-times-weekly rFVIII-FS $(n=125)$ in adolescent and adult patients with severe hemophilia A. The total study duration will be 52 weeks (fig. 3). To date, more than 1,500 liposomal injections have been given; only one serious adverse event related to treatment with BAY 79-4980 (moderate hypersensitivity) has been reported.*

Dr Lemm presented further data on a novel rFVIIa product, which is aimed at treating patients with hemophilia A or hemophilia B who have inhibitors. The product, BAY 86-6150, is currently being investigated in a randomized, placebo-controlled, phase I dose-escalation trial. The molecular design of the molecule has been shown to enable a rapid burst of thrombin generation and stable clot formation. The addition of two N-glycans was further shown to increase circulating half-life. In FVIII knock-out mice, BAY 86-6150 significantly increased survival following induction of severe hemorrhage, compared with rFVIIa at varying doses or a simple vehicle ( $\mathrm{P}<0.01$ versus vehicle). A total of 16 hemophilia A and B patients with and without inhibitors have so far been recruited to the phase I dose-escalation trial. The key assessments of the study are safety and tolerability, pharmacokinetics, coagulation markers, and immunogenicity at 30 and 50 days post-dosing.

\section{Next-Generation Coagulation Factors}

Current FDA-approved recombinant coagulation factors are generally considered to be well-tolerated and efficacious; therefore, next-generation coagulation products must be of equal tolerability yet provide a better standard of care for patients. Greater understanding of the relationship between structure and function of the native proteins allows the design of molecules with potentially new properties such as prolonged half-life and enhanced activity.

John Murphy of Bayer HealthCare Pharmaceuticals provided an overview of the strategies involved in designing novel coagulation factors, and presented data on the effects of engineered changes to the protein molecules on their mechanism of action. For example, native FVIIa is the weakest platelet binder of all the Gla-containing proteins; therefore, a novel molecule was engineered using techniques of DNA shuffling and screening to produce a molecule with higher affinity for platelets. Novel $\mathrm{N}$-glycosylation sites were also engineered to increase the circulating half-life of the product (fig. 4). The resulting coagulation factor, BAY 86-6150, was found to have a substantially higher affinity for activated platelets than wild-type FVIIa and was thus able to reduce clotting time by a greater amount in the presence of activated platelets compared with rFVIIa. In in vivo studies, the proportion of hemophilia A mice surviving for $6 \mathrm{~h}$ post tail-vein transection was significantly improved by the administration of BAY 86-6150 compared with rFVIIa.

A longer acting FVIII requiring only once-weekly dosing is also an unmet medical need. One strategy for prolonging hemostatic activity is to noncovalently bind the molecule to PEGylated liposomes, as was discussed by Dr Lemm.* Another strategy is site-specific covalent conjugation of PEG to FVIII. In ongoing research, a total of 32 sites in multiple domains of FVIII have been screened as substrates for PEG conjugation, leading to the identification of a number of sites that could be effectively PEGylated and maintain activity. In vivo studies demonstrated that PEGylation increased half-life of FVIII while maintaining full acute activity. Controlled phase I trials investigating the efficacy and tolerability of these products in a clinical setting are ongoing for BAY 86-6150 and are planned for site-specific PEGylation of FVIII.

L.A. Valentino, Chicago, IL, USA M.J. Manco-Johnson, Denver, CO, USA E. C. Rodriguez-Merchan, Madrid, Spain G. Lemm, Leverkusen, Germany J.E. Murphy, Richmond, CA, USA

* Post Meeting Note: An independent Data Safety and Monitoring Board (DSMB) completed an interim analysis of this phase II trial (the LIPLONG study) of Bayer's long-acting recombinant factor VIII, BAY79-4980. The DSMB concluded that the study will not be able to achieve the predetermined efficacy endpoint (non-inferiority). No safety concerns were raised. As a result of the DSMB findings and recommendation, Bayer decided to discontinue the study.

\section{Acknowledgements}

The symposia and publication were made possible by funding from Bayer HealthCare Pharmaceuticals. Emily Marlow of Porterhouse Medical Limited provided medical writing assistance in the development of the manuscript.

\section{References}

1 Centers for Disease Control and Prevention: Bleeding and clotting disorders surveillance, 2009

2 Soucie JM et al.: Joint range-of-motion limitations among young males with hemophilia: Prevalence and risk factors. Blood 2004;103:2467-2473.

3 Miners AH et al.: Assessing health-related quality-oflife in individuals with haemophilia. Haemophilia 1999;5:378-385.

4 Poonnoose PM et al.: Functional independence score in haemophilia: A new performance-based instrument to measure disability. Haemophilia 2005;11:598-602.

5 Pollmann $\mathrm{H}$ et al.: When are children diagnosed as having severe haemophilia and when do they start to bleed? A 10-year single-centre pup study. Eur J Pediatr 1999;158(suppl 3):S166-170.

6 Fischer $\mathrm{K}$ et al.: The effects of postponing prophylactic treatment on long-term outcome in patients with severe hemophilia. Blood 2002;99:2337-2341.

7 Valentino LA et al.: Blood-induced joint disease: The confluence of dysregulated oncogenes, inflammatory signals, and angiogenic cues. Semin Hematol 2008;45:S50-57.

8 Nilsson IM et al.: Haemophilia prophylaxis in Sweden. Acta Paediatr Scand 1976;65:129-135.

9 Manco-Johnson MJ et al.: Prophylaxis versus episodic treatment to prevent joint disease in boys with severe hemophilia. N Engl J Med 2007;357:535-544.

10 Hacker MR et al.: Central venous access device infections in children with hemophilia: A comparison of prophylaxis and episodic therapy. J Pediatr Hematol Oncol 2007;29:458-464.

11 Rodriguez-Merchan EC et al.: Radioactive synoviorthesis for the treatment of haemophilic synovitis. Haemophilia 2007; 13(suppl 3):32-37.

12 Silva $\mathrm{M}$ et al.: $32 \mathrm{p}$ chromic phosphate radiosynovectomy for chronic haemophilic synovitis. Haemophilia 2001; 7(suppl 2):40-49.

13 Manco-Johnson MJ et al.: $32 \mathrm{p}$ radiosynoviorthesis in children with hemophilia. J Pediatr Hematol Oncol 2002;24:534-539.

14 Chew EM et al.: Radionuclide synovectomy and chronic haemophilic synovitis in asians: A retrospective study. Haemophilia 2003;9:632-637.

15 Grmek M et al.: Radiosynoviorthesis for treatment of hemophilic hemarthrosis-slovenian experience. Cancer Biother Radiopharm 2005;20:338-343.

16 Fernandez-Palazzi $\mathrm{F}$ et al.: Chemical synoviorthesis with oxytetracycline clorhydrate (emicine) in recurrent haemarthrosis. Haemophilia 2008;14:21-24.

17 Journeycake JM et al.: Arthroscopic synovectomy in children and adolescents with hemophilia. J Pediatr Hematol Oncol 2003;25:726-731.

18 Dunn AL et al.: Arthroscopic synovectomy for hemophilic joint disease in a pediatric population. J Pediatr Orthop 2004;24:414-426.

19 Rodriguez-Merchan EC: Total knee replacement in haemophilic arthropathy. J Bone Joint Surg $\mathrm{Br}$ 2007;89:186-188.

20 Spira J et al.: Prolonged bleeding-free period following prophylactic infusion of recombinant factor viii reconstituted with pegylated liposomes. Blood 2006;108:3668-3673.

\section{Impressum}

\section{Meeting Report: ISTH 2009}

Hemophilic Arthropathy: New Insights into Mechanisms, Prevention and Management Innovationen in

Transfusion Medicine and Hemotherapy 37 | 5 | 10

(C) 2010 by S. Karger Verlag für Medizin und Naturwissenschaften $\mathrm{GmbH}$

Wilhelmstraße 20A

79098 Freiburg, Deutschland

Mit freundlicher Unterstützung von Bayer HealthCare Pharmaceuticals.

Der Verlag und die Herausgeber der Zeitschrift übernehmen keine Verantwortung für diese Rubrik. 


\section{Hohe Produktqualität und intensive Forschung}

Mit der vollständigen Integration von Wyeth ist der Bereich Hämophilie und damit die beiden rekombinanten Faktorpräparate ReFacto $A F^{\circledR}$ (Moroctocog alfa) und BeneFIX ${ }^{\circledR}$ (Nonacog alfa) seit 1. Juli 2010 unter dem Dach von Pfizer angesiedelt. Bei beiden Unternehmen bestimmten bislang Qualitätsbewusstsein, Innovationskraft und Kundenorientierung das Handeln und Forschen. Daran wird Pfizer weiterhin festhalten, damit in der Zukunft noch bessere Präventions- und Therapieoptionen zur Verfügung stehen. Ärzte und Patienten können sich damit auch künftig auf die gewohnt hohe Qualität in Bezug auf Wirksamkeit und Sicherheit der Präparate verlassen. In der Forschung verfolgt Pfizer den Ansatz von Wyeth weiter und konzentriert sich auch in Zukunft darauf, vorhandene Produkte weiter zu verbessern und parallel neue therapeutische Möglichkeiten zu entwickeln, mit dem Ziel, den Patienten die optimale Therapie zur Verfügung zu stellen.

\section{Das Unternehmen Pfizer}

Das forschende Arzneimittelunternehmen Pfizer hat es sich zur Aufgabe gemacht, die Gesundheit und die Lebensqualität von Patienten wiederherzustellen oder zu verbessern. Durch den Zusammenschluss mit Wyeth erweitert das Pharmaunternehmen sein Portfolio um das der Biopharmazeutika und ist dadurch noch besser in der Lage, neue oder optimierte Therapien, gerade auch für seltene Erkrankungen wie die Hämophilie, zu entwickeln.

\section{Ziele von Pfizer Hämophilie}

Wie schon für Wyeth steht auch für Pfizer der Patient im Fokus. Damit wird Pfizer den von Wyeth beschrittenen Weg weitergehen, durch kontinuierliche Erforschung und Weiterentwicklung der Faktorkonzentrate die Situation von Hämophilie-Patienten in Bezug auf Sicherheit und Anwenderfreundlichkeit der Präparate zu optimieren. Auch die von Wyeth begonnenen Forschungsansätze werden weiterverfolgt, wie z.B. die Entwicklung neuer Applikationsformen, um die Handhabung bereits bestehender Therapien zu verbessern. Ein weiteres Ziel ist die Verlängerung der Halbwertszeit der aktuellen Präparate, wodurch eine seltenere Faktorsubstitution nötig wäre und damit die Therapie für Patienten erleichtert würde.

\section{Das A und B der Hämophilie}

Hämophilie A und Hämophilie B sind X-chromosomal vererbte Gendefekte, von denen fast ausschließlich Männer betroffen sind. Der Defekt führt zu Blutgerinnungsstörungen, die auf einem Mangel an Gerinnungsfaktoren basieren. In Deutschland gibt es etwa 4000 HämophiliePatienten, wobei bei männlichen Neugeborenen die Hämophilie A eine Inzidenz von etwa 1:10000 und die Hämophilie $B$ eine von 1:25000 aufweist. Durch den Mangel an Faktor VIII bzw. IX ist der Ablauf der Gerinnungskaskade gestört, so dass Fibrin nur unzureichend gebildet wird und damit kein stabiles Fibrinnetz zur Blutstillung entsteht. Je nach Schweregrad kann es bereits im Säuglingsalter zu Spontanblutungen und Blutungen nach Bagatelltraumen kommen. Unbehandelt kann die Erkrankung zu Bewegungseinschränkungen bis hin zur Invalidität führen. Durch eine prophylaktische Infusionstherapie, die bei Kindern mit schwerer Hämophilie die Therapie der Wahl ist, oder auch eine On-demand-Therapie, d.h. eine Therapie bei Bedarf (im Falle einer aufgetretenen Blutung) mit Faktor VIII bzw. IX lässt sich ein Großteil der Blutungen verhindern bzw. deren Folgeschäden vermindern und dadurch die Lebensqualität sowie die Lebenserwartung der Patienten deutlich verbessern.

\section{ReFacto AF $^{\circledR}$ und BeneFIX ${ }^{\circledR}$ : Bewährte Qualität - neue Optik}

Mit der Übernahme der Wyeth-Produkte ReFacto $\mathrm{AF}^{\circledR}$ (Moroctocog alfa) und BeneFIX ${ }^{\circledR}$ (Nonacog alfa) ist Pfizer der einzige Anbieter

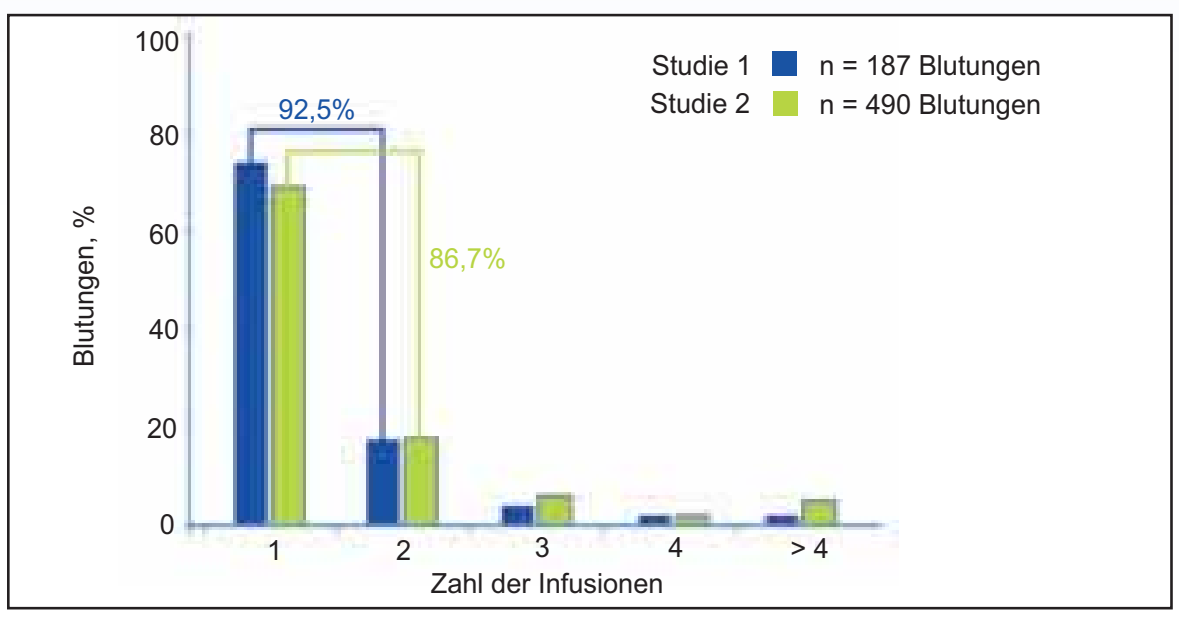

Abb. 1. Wirksamkeit in der Bedarfsbehandlung. zweier rekombinanter Präparate zur Behandlung der Hämophilie A und B. Die beiden Faktorkonzentrate werden bereits seit über 10 Jahren erfolgreich zur Prophylaxe und Therapie der Hämophilie A und B bei Kindern aller Altersstufen und Erwachsenen eingesetzt.

\section{ReFacto $\mathrm{AF}^{\circledR}$ - Sicher und wirksam bei Hämophilie A}

Das rekombinante Faktor-VIII-Präparat ReFacto $\mathrm{AF}^{\circledR}$ wird seit Juni 2009 zur Therapie der Hämophilie A eingesetzt. Es handelt sich um eine Weiterentwicklung des bereits vor über 10 Jahren eingeführten und seitdem bewährten ReFacto ${ }^{\circledR}$. Bei beiden Produkten wird das gleiche Wirkstoffmolekül verwendet. Wie schon das Vorgängerpräparat ist auch ReFacto $\mathrm{AF}^{\circledR}$ von der für die Blutgerinnung bedeutungslosen B-Domäne befreit, jedoch wurde der Herstellungsprozess entscheidend verbessert.

\section{Verbesserungen in der Herstellung}

Bei ReFacto $\mathrm{AF}^{\circledR}$ wird erstmalig bei der Herstellung eines Faktor-VIII-Präparats ein chemisch synthetisierter Affinitätsligand bei der Aufreinigung eingesetzt [1]. Dieser Ligand ersetzt den bisherigen monoklonalen Mausantikörper in der sogenannten Affinitätschromatographie, die zur Aufreinigung des Präparats verwendet wird. Ferner ist bereits das Medium der CHO-Zelllinie frei von humanem Serumalbumin. Weder bei der Herstellung noch bei der Aufreinigung kommen somit humane oder tierische Fremdproteine zum Einsatz. Damit ist 
ein potenzielles Kontaminierungsrisiko durch menschliches Blut ausgeschlossen. Zudem wird im Aufreinigungsprozess eine Nanofiltration verwendet. Durch die Weiterentwicklung des Herstellungsprozesses verfügt ReFacto $\mathrm{AF}^{\circledR}$ über eine hohe Reinheit und Virussicherheit.

\section{Wirksamkeit und Sicherheit}

Moroctocog alfa, der Wirkstoff in ReFacto $\mathrm{AF}^{\circledR}$, wurde vor der Zulassung in zwei klinischen Studien [2] untersucht, wobei alle Patienten eine moderate oder schwere Hämophilie A hatten. Unter einer prophylaktischen Therapie traten bei 45,7\% in Studie 1 und 24\% in Studie 2 gar keine Blutungsepisoden auf, also auch keine traumatischen Blutungen. Zudem hatten 60,6\% (Studie 1) bzw. $49 \%$ (Studie 2) der Patienten keine Spontanblutungen. In der On-demand-Behandlung von Blutungen zeigte sich Moroctocog alfa ebenfalls effektiv. So konnten $92,5 \%$ der Blutungen in Studie 1 mit 1-2 Infusionen gestillt werden, bei der Mehrheit $(74,3 \%)$ reichte eine einzige FVIII-Gabe aus. In Studie 2 wurden $86,7 \%$ der Blutungen mit 1-2 Infusionen gestoppt (Abb.1). 86\% der Ärzte und Patienten bewerteten dabei die Wirksamkeit der ersten Infusion mit «exzellent» oder «gut».

\section{BeneFIX ${ }^{\circledR}$ - Richtungsweisend bei Reinheit und Sicherheit}

BeneFIX $^{\circledR}$ (Nonacog alfa) wird seit nunmehr 12 Jahren zur Therapie und Prophylaxe von Blutungen bei Hämophilie-B-Patienten eingesetzt. BeneFIX ${ }^{\circledR}$ ist das erste und einzige zugelassene rekombinante Faktor-IX-Präparat und damit richtungsweisend bei Reinheit und Sicherheit. Es ist bereits in seiner Zellkultur frei von humanen oder tierischen exogenen Eiweißen. Aufgrund des Einsatzes rekombinanter Technologie ist ein Kontaminierungsrisiko durch menschliches Blut ausgeschlossen [3]. Zudem wird es in 4 Chromatographie- und 5 Filtrationsschritten gereinigt und aufbereitet, wodurch eine hohe Reinheit sowie hohe Homogenität erzielt wird (Abb. 2).

\section{Wirksam und sicher in allen Therapiesituationen} Ergebnisse klinischer Studien zeigen für BeneFIX ${ }^{\circledR}$ eine konsistent gute klinische Wirksamkeit und Sicherheit - sowohl in der Prophylaxe als auch in der On-demand-Therapie und bei Operationen - bei vorbehandelten und nicht vorbehandelten Patienten [4-6]. So untersuchte eine Studie [4] an 56 bereits zuvor behandelten Patienten mit schwerer oder moderater Hämophilie B über 2 Jahre die Wirksamkeit und Sicherheit von BeneFIX ${ }^{\circledR}$. Die Studie zeigte, dass alle auftretenden Blutungen kontrolliert werden konnten. Dabei waren in 92,5\% der Fälle bereits
1-2 Infusionen ausreichend. In der prophylaktischen Therapie sowie bei Operationen war BeneFIX ${ }^{\circledR}$ ebenfalls effektiv. Auch in Bezug auf die Sicherheit überzeugte BeneFIX ${ }^{\circledR}$. Nur ein Teilnehmer entwickelte einen niedrigtitrigen transienten Inhibitor, bei $98 \%$ der Teilnehmer kam es zu keinerlei Inhibitorbildung. Zudem wurden in der bislang größten offenen multizentrischen Studie [5] zur Hämophilie B 63 zuvor unbehandelte Patienten mit schwerer oder moderater Hämophilie B mit BeneFIX ${ }^{\circledR}$ behandelt. Es zeigte sich, dass bei $89,9 \%$ der Patienten mit 1 oder 2 Infusionen eine Blutstillung erzielt werden konnte. Auch in der prophylaktischen Behandlung sowie bei Operationen wurde eine wirksame Blutstillung erreicht. Nur bei 5 Patienten zeigten sich innerhalb von $48 \mathrm{~h}$ nach der Therapie allergische Reaktionen, 2 davon entwickelten einen Inhibitor.

\section{Effektive Prophylaxe bei Kleinkindern}

In einer prospektiven Studie [6] an Kindern unter 6 Jahren wurde zudem belegt, dass bei schwerer Hämophilie B eine frühzeitige Prophylaxe mit BeneFIX ${ }^{\circledR}$ bei Kleinkindern sicher und wirksam ist. So traten innerhalb von 6 Monaten bei $77 \%$ von 22 zuvor nicht behandelten Kleinkindern keine spontanen Gelenkblutungen und bei $32 \%$ keinerlei Blutungen auf. Dies wurde bereits durch eine 1- bis 2-malige prophylaktische Gabe pro Woche von Nonacog alfa erzielt.

\section{Zukunft der beiden Präparate}

Der Herstellungsprozess und damit die gewohnt hohe Qualität und Anwenderfreundlichkeit der Präparate werden auch unter dem Dach von Pfizer erhalten bleiben. Änderungen wird es ausschließlich bei der Verpackung geben. Als erster Schritt wird ab Herbst 2010 das Wyeth-Logo durch das Logo von Pfizer ersetzt werden. In einem zweiten Schritt wird es weitere kleine Modifikationen der Packungsgestaltung geben, über die alle Ärzte und besonders die Patienten noch gesondert informiert werden.

\section{Die Zukunft der Hämophilie bei Pfizer}

Ein Forschungsschwerpunkt von Pfizer wird auch in Zukunft darauf liegen, bekannte Wirkmoleküle mithilfe von biotechnologischen Verfahren therapeutisch nutzbar zu machen. So arbeitet Pfizer im Moment zusammen mit Catalyst Biosciences an Bypass Agents mit verbesserten therapeutischen Eigenschaften, wie z.B. einem rekombinanten Faktor VIIa. In ersten Untersuchungen konnte bereits eine erhöhte Halbwertszeit, Wirksamkeit sowie Wirkdauer im Tiermodell nachgewiesen werden. Ferner ist der Faktor

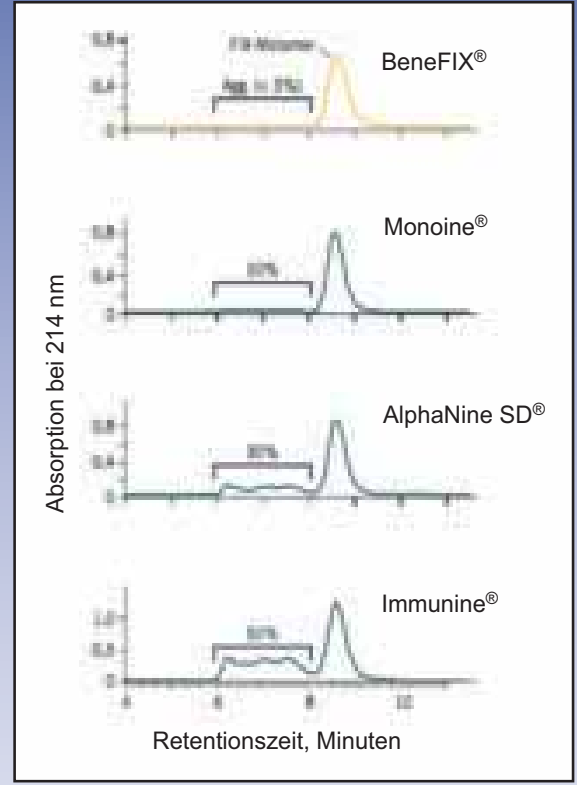

Abb. 2. Reinheitsgrad des Faktor IX in BeneFIX ${ }^{\circledR}$ im Vergleich zu anderen Produkten - GrößenausschlussChromatografie.

Xa für Forscher besonders interessant, da er der einzige Aktivator von Prothrombin ist. Bislang konnte der Faktor Xa aber therapeutisch nicht genutzt werden, da er im Plasma zu rasch inaktiviert wird. Nun ist es jedoch gelungen, eine Faktor XaVariante herzustellen, die sich im Plasma ähnlich verhält wie ein Proenzym und eine verlängerte Halbwertszeit aufweist. Diese Variante stellt die Hämostase her, ohne die Gerinnung exzessiv zu aktivieren, und ist damit ein vielversprechender Ansatz für die Zukunft der Hämophilietherapie.

\section{Referenzen}

1 Kelley BD et al.: Biotechnol Bioeng 2004;87(3): 400-412.

2 Recht M et al.: Haemophilia 2009;15(4):869-880.

3 Harrison $S$ et al.: Semin Hematol 1998;35(suppl 2): 4-10.

4 Roth D et al.: Blood 2001;89(13):3600-3606.

5 Shapiro AD et al.: Blood 2005;105(2):518-525.

6 Monahan PE et al.: Haemophilia 2010;16(3): 460-468.

\section{Impressum}

Pfizer Hämophilie:

Hohe Produktqualität und intensive

Forschung

Innovationen in

Transfusion Medicine and Hemotherapy 37 | 5 | 10

(C) 2010 by S. Karger Verlag für Medizin

und Naturwissenschaften $\mathrm{GmbH}$

Wilhelmstraße 20A

79098 Freiburg, Deutschland

Mit freundlicher Unterstützung von Pfizer Pharma GmbH.

Der Verlag und die Herausgeber der Zeitschrift übernehmen keine Verantwortung für diese Rubrik. 
Neuer Standard für Sicherheit beim Bluttest

\section{Vollautomatisierter direkter HIV- und Hepatitis-Virus-Nachweis in Einzeltestung}

Bluttransfusionen und aus Spenderblut hergestellte Blutprodukte gelten heute durch moderne Testverfahren als sehr sicher. Grundsätzlich bleibt insbesondere durch okkult Hepatitis-B-infizierte Spender (OBI) ein geringeres Restrisiko bestehen. Mit dem PROCLEIX ${ }^{\circledR}$ ULTRIO $^{\circledR}$ Plus Test, einem neuen Modul des PROCLEIX ${ }^{\circledR}$ TIGRIS ${ }^{\circledR}$ Systems, denn damit lassen sich individuelle Blutproben vollautomatisch und hochsensitiv direkt auf HIV, HCV und HBV testen. Auf dem 31. Jahreskongress der International Society of Blood Transfusion (ISBT) wurde ebenfalls deutlich, dass durch die rationelle Einzelspendentestung das diagnostische Zeitfenster im Vergleich zur Pooltestung verkürzt werden kann.

«Das Ziel muss die größtmögliche Sicherheit beim Bluttest sein», gab Professor Jean-Pierre Allain, Cambridge, Großbritannien, zu bedenken. Obwohl die medizinischen Folgen einer HBV-Infektion medizinisch nicht so gravierend sind wie eine HIV- oder HCV-Infektion, gibt es andererseits jedoch ein wesentlich gröBeres Restrisiko durch HBV; zudem wird weltweit immer mehr von transfusionsbedingten HBV-Infektionen berichtet. Testsysteme, die NAT (Nukleinsäuretest, Nucleic Acid Test) nutzen, gelten als wesentlich sensitiver als serologische Tests. «Allerdings waren die bisherigen Pooltestungen nicht genügend empfindlich, um das Risiko signifikant zu vermindern», sagte Dr. Christoph Niederhauser, der Leiter Labordiagnostik des Blutspendedienstes Bern, Schweiz. Daher wurde dort auf den PROCLEIX ${ }^{\circledR}$ ULTRIO $^{\circledR}$ Plus Test zurïckgegriffen, welcher die simultane Detektion von HIV-1, HCV und HBV direkt anhand von Einzelproben ermöglicht. «Die Extraktion, Amplifikation und Detektion findet für alle 3 Viren kann dieses Risiko noch weiter minimiert werden,

im selben Röhrchen statt», so Niederhauser weiter. Die Reinigung der Nukleinsäure wird mittels magnetischer Mikropartikel durchgeführt. Die Amplifikation basiert auf der Transcription Mediated Amplification (TMA) Technology, bei der virusspezifische RNA-Fragmente isothermal vermehrt werden.

\section{Deutliche Risikoreduzierung von HBV- Infektionen}

«Die mit diesem NAT-System erreichten Sensitivitäten bei mehr als 525000 durchgeführten Tests sind deutlich besser als die gesetzlichen Mindestanforderungen», berichtete der Tranfusionsspezialist. Insbesondere bei HBV konnte in einen Bereich vorgestoßen werden, in dem auch sehr niedrige Viruslasten noch problemlos nachgewiesen werden können. So wurden mit dem PROCLEIX ${ }^{\circledR}$ TIGRIS $^{\circledR}$ System (Abb. 1) 8 Spenden entdeckt, die im obligatorisch vorgeschriebenen $\mathrm{HBs} A g-S c r e e n i n g$ negativ waren. Bei diesen Spenden handelte es sich in zwei Fällen um eine ganz frische Infektion und in 6 Fällen um eine chronische HBV-Infektion (OBI) des entsprechenden Spenders. Der Experte verwies darauf, dass nicht nur OBI-Infektionen aufgedeckt werden konnten, sondern dass auch das kritische Zeitfenster von der Infektion bis zur Nachweisbarkeit reduziert werden konnte. Dies wurde besonders deutlich bei HBV-Infektionen, wo sich das diagnostische Zeitfenster um fast $60 \%$ reduzieren ließ. Niederhauser schlussfolgerte: «Die von uns erarbeiteten Daten sprechen eindeutig dafür, dass mit der NATTestung im Einzelspendenformat Blutprodukte zu entdecken sind, welche potenziell zu einer HBV-Infektion eines Empfängers führen können.»

\section{Analytische Sensitivität}

- Die Sensitivität hinsichtlich HCV und HIV-1 ist vergleichbar

HBV verschiedener Genotypen werden durch ULTRIO ${ }^{\circledR}$ Plus mit dreifach höherer Sensitivität detektiert

Klinische Sensitivität

- $\quad$ Die HBV-DNA-Detektion bei HBsAg-Trägern stieg von 95 auf $98 \%$ (ULTRIO ${ }^{\circledR}$ Plus)

- $\quad$ OBI werden durch ULTRIO ${ }^{\circledR}$ Plus mit neunfach höherer Sensitivität detektiert

Spezifität von ULTRIO ${ }^{\circledR}$ Plus

- $\quad 99,7 \%$ als initiales Screening-Resultat

- $100 \%$ im wiederholten Testalgorithmus

Tab. 1. Sensitivität und Spezifität des PROCLEIX ${ }^{\circledR}$ ULTRIO $^{\circledR}$ Tests im Direktvergleich mit dem neuen ULTRIO ${ }^{\circledR}$ Plus Test

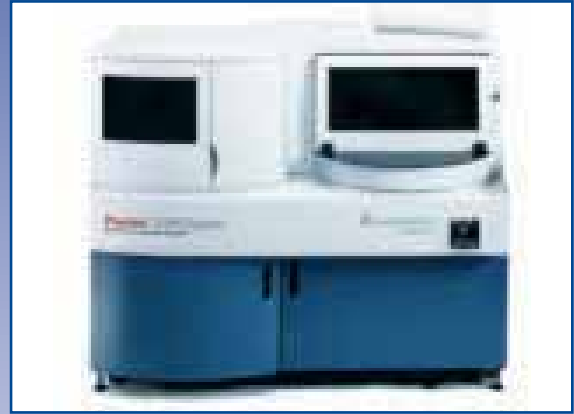

Abb. 1. PROCLEIX ${ }^{\circledR}$ TIGRIS $^{\circledR}$ System.

TMA-Test der zweiten Generation überzeugt im Direktvergleich

Mit dem PROCLEIX ${ }^{\circledR}$ ULTRIO $^{\circledR}$ Plus Test liegt nun die zweite Generation der Testmodule für das PROCLEIX ${ }^{\circledR}$ TIGRIS $^{\circledR}$ System vor. Dieses erweist sich dem Vorgängertest als überlegen hinsichtlich analytischer und klinischer Sensitivität, wie ein von der Arbeitsgruppe von Dr. Piotr Grabarczyk, Warschau, Polen, durchgeführter Direktvergleich eindrucksvoll belegt. Das neue ULTRIO ${ }^{\circledR}$ Plus System enthält mit Lithiumhydroxid eine zusätzliche, verstärkende Substanz für die Zielsignale. Die Ergebnisse des Direktvergleiches stellen klar, dass es sich bei dem ULTRIO $^{\circledR}$ Plus Test um eine Weiterentwicklung handelt, mit der die Spezifität und Sensitivität des Bluttestes noch erhöht werden kann (Tab. 1).

Das Fazit von Grabarczyk lautete daher: «Dieses neue technische Verfahren bedeutet eine weitere entscheidende Verbesserung, denn das sehr geringe Restrisiko kann noch weiter minimiert werden. Damit ist die größtmögliche Sicherheit gewährleistet und das mit einem System, welches einfach und ohne großen Aufwand zu bedienen ist.»

Dr. Bettina Reich, Hamburg

\section{Quelle}

Symposium «Setting New Standards in Blood Safety Testing» im Rahmen des ISBT, Veranstalter: Novartis Diagnostics.

\section{Impressum \\ Neuer Standard für Sicherheit beim Bluttest Vollautomatisierter direkter HIV- und Hepatitis-Virus-Nachweis in Einzeltestung Innovationen in \\ Transfusion Medicine and Hemotherapy 37 | 5 | 10 \\ (C) 2010 by S. Karger Verlag für Medizin und Naturwissenschaften $\mathrm{GmbH}$ \\ Wilhelmstraße 20A 79098 Freiburg, Deutschland}

Mit freundlicher Unterstützung von Novartis Diagnostics.

Der Verlag und die Herausgeber der Zeitschrift übernehmen keine Verantwortung für diese Rubrik. 